\title{
The Shift in The Tradition of Islamic Education in Indonesia from The 19th Century to The Early 21st Century
}

\author{
Saefudin \\ Biro Kepegawaian, Sekretariat Jendral, Kementerian Agama RI, \\ Jl. Lapangan Banteng Barat 3-4, Jakarta Pusat \\ E-mail: saef.syafii@gmail.com
}

Abstract: This paper examines the Indonesian Islamic education tradition from the 19th Century to the early 21st Century. The data in this paper were obtained from written sources as well as several previous studies. The results reveal that the Islamic education tradition begins with religious recitation, which is taught individually (not collectively or in a classical system) in a teacher's house, langgar, or surau. The relationship pattern between Islamic (pesantren-madrasah) and the regular education system is associated with Indonesia's Islamic education system development. This pattern occurred in the 19th to the beginning of the 21st Century and is divided into two episodes. During the first two centuries (19th and 20th centuries), the Islamic education system (religious sciences organized by individuals, organizations, or government institutions) was still differentiated (convergence or synthesis) from the ordinary school education system (general sciences). At the beginning of the 21st Century, the relationship between the two education systems has indicated knowledge integration, although it is still minimal. So far, it has been rigidly divided between "religious sciences" on the one hand and "general sciences" on the other, leading to an integrated knowledge discourse. If this pattern is desired, an Islamic boarding school for higher education will be created. Where "general knowledge" is given during the day, and "religious knowledge" (The Qur'an and Kitab) is taught in the evening. This tradition has become a model for curriculum synthesis between the religious sciences and the general sciences to form the Islamic higher education institution. 
IBDA': Jurnal Kajian Islam dan Budaya

Keywords: Tradition, Islamic Education, Integration of knowledge, Indonesia.

\section{A. Introduction}

With a decree dated $M$ arch 18, 1819, Governor-G eneral Van der Capellen ordered research on the education (Islamic) of the Javanese people, in particular, intending to improve reading and writing skills among them. From these studies' results, it is hoped that the implementation of education laws and regulations can be improved (Stenbrink, 1994: 3). A bout a century later, $B$ rugmans discussed the official report of research on J ava, as cited by Stenbrink (1994: 3) and suspected that Governor-General Van der Capellen wanted to carry out a type of education "based purely on indigenous people, on a regular basis and adapted to the village community, which was closely linked to pre-existing Islamic education."

The first figure among Dutch colonial government employees who worked fully for education was the Indigenous E ducation I nspector, J .A. Van der Chijs. In 1865, a year after serving as Inspector of Education, he had already refused to adapt the existing Islamic Education, based on technical (not substantial) educational reasons. One of which was the bad habits of reading A rabic texts, which are only memorized, without giving meaning (Stenbrink, 1994: 3). A the same time, in M inahasa and M aluku, there are many schools established and managed by zending, which receive subsidies from the government. This school is 100 percent focused on religious education (Christianity) (Stenbrink, 1994: 4). If The Qur' an written in A rabic is the main book for some types of Islamic education, then in zending schools, the B ible's translation in M alay is the most important book. Van der Chijs then proposed that the quality of general lessons in the school (zending) be repaired and improved, while religious lessons are reduced.

In 1888, the Colonial M inister refused to provide Islamic school subsi dies because it did not benefit the colonial government. A s a replacement, they established what was called village schools, a simple educational institution that paved the way for general education (Stenbrink, 1994: 7). At that time, the proposal to incorporate Islamic education was rejected. Since then, Islamic schools have taken their path independently apart from the governorship, where they stick to their traditions but are al so open to changes 
to an integrated education system.

Since the beginning of the 20th Century, Islamic education has begun to develop its education model that is different and separate from the Dutch education system and the education system implemented by the Indonesian $M$ inistry of E ducation and Culture. Indonesia's general education system does not arise due to its adjustment to the traditional I slamic education system. On the other hand, as it is today, the Islamic education system is the one that is gradually adjusting itself and entering the general education system (Stenbrink, 1994: 7).

B ased on the description above, the short article explores the shift in the tradition of I slamic education, which was initially differentiated from general education - from the 19th to the early 21 st Century. M ore precisely, from the colonial era, the era of Indonesian independence, until the era of devel opmenttowards an integrated I slamic education system, generally in Indonesia, especially in Java.

\section{B. The teaching of The QuR' An, The Teaching of The Reli- GIOUS BOOK (КITAB), AND ISLAMIC BOARDING SCHOOL (PE- SANTREN) AS THE EARLY TRADITION OF ISLAMIC EDUCATION}

Since the beginning of the Islamic era, there have been two educational traditions, apart from primary education and higher education (R ahman, 1984: 264). The first was royal school education, which was held for royal born children to prepare them for future government leaders. A Ithough this educational tradition includes religious lessons, it only emphasizes the formality side, such as speeches, literature, etc. The second was adult school education, the main purpose of which is to teach them about The Qur' an and religion, not reading nor writing skills. In this education system, religious studies have become substantial, no longer formal. From this second educational tradition, high-level schools grow through halaqah-halaqah or groups, namely students who gather around a particular teacher (Rahman, 1984: 264). By teaching The Qur' an and the classical books (popularly known as K itab K uning/yellow books), the halaqah system was later adopted by pesantren architects in J ava, particularly after studying in the M iddle East, especially M ecca, in the 19th Century (M as' ud, 2006: 109-268). 
IBDA': Jurnal Kajian Islam dan Budaya

\section{The Tradition of Teaching The Qur'an}

The most basic Islamic education is entirely centered on T he Q ur' an and is called The Qur' an recitation (Rahman, 1984: 263). This educational model is in the form of a tradition of reading several parts of The Q ur' an. For starters, the surah A I-Fatihah is taught, and then it is followed by short surahs (juz 'A mma), which are essential for performing worship. Thus, the teaching of worship in early Islamic education is highly prioritized; consequently, the knowledge of laws (figh) on worship is the earl iest subject taught (Stenbrink, 1994: 10). In this recitation, the students learn A rabic letters and memorize the texts contained in T he Q ur' an. B esides, the rules and regulations regarding obligatory prayers, ablution, and other forms of daily prayers are also being taught. All of the subjects taught in these recitations are very dependent on the teacher's cleverness, and thus the characteristic of the early Islamic education model is still individual (Stenbrink, 1994: 10).

These educational traditions are taught individually at a teacher's house, langgar, or surau. However, in some cases, it is al so carried out in the student's house, especially if the parents have an important position (Stenbrink, 1994: 10). There are often large differences in learning time in this individualized education system, where there are fast students. However, some are slow in completing their education. The main goal in this individual type of primary education has been achieved if the student has finished reading The Qur' an as a whole for the first time (Stenbrink, 1994: 10). Reading here has the meaning of pronouncing verses from The Qur' an because, at this phase, the textual content of this holy book has not been taught. When this recitation is finished, usually a khatam ceremony will be held. This event is complemented by the male circumcision, which is considered an important starting point in Islamic life. A fter this event, students are considered puberty (adults) and are obliged to perform worship such as prayer, fasting, and so on (Stenbrink, 1994: 10). This type of education is still developing today, especially in certain areas where there is still a strong sense of respect for an individual who has advantages in the field of religion. In later devel opments, this pattern created the concept of "kyai center" or "ajengan center," where kyai as a person is the center of the Islamic boarding school (pesantren), instead of the education (Stenbrink, 1994: 10). It is the charisma of an individual kyai that measures a pesantren's quality, not the knowledge it teaches. 
Saefudin: The Shift in The Tradition of Islamic Education... (page 1-23)

\section{The Tradition of Teaching the Religious B ook (Kitab)}

The tradition of reciting religious books ( $\mathrm{K}$ itab) is different from The Qur' an recitation that has been mentioned above. According to Stenbrink (1994: 12), this difference can be seen from three aspects: First, students of this book recitation generally enter a dormitory within an Islamic religious education institution called pesantren. Second, the first phase of the K itab recitation education generally begins with language education. Third, education is no longer given individually, but also in groups or classically. In this phase, there has been a shift from reciting The Qur' an to the teaching of $K$ itab. In turn, this shift has changed the style of education from an individual to a classical style.

A ccording to Stenbrink (1994: 171), the first level of reading the Kitab is learning the A rabic language. Students must read and memorize the A rabic text without error, and then the teacher explains the contents and meaning of the text word for word to them. The hallmark of the pesantren education tradition is thus muhafazah (memorization or rote). A lthough this language's teaching does not directly concern religious matters, the pesantren atmosphere, where the students live, is thoroughly permeated with A rabic teaching, making A rabic teaching regarded entirely as religious teaching (Stenbrink, 1994: 171). The bad implication is, there is a correlation identification that Islam is A rabic, and A rabic is the language of Islam.

The length of time studying the language (for example, nahwu science) can vary, from six months to six years, depending on the students' respective kyai and talents. Language teaching that takes years is then deemed ineffective. In addition to the length of time it takes, the religious material studied is limited to tools, not the content, because the latter is the most important (Stenbrink, 1994: 171). To break through this deadlock, lately, there have been many concise methods of reading the yellow book, either in the form of a special $\mathrm{K}$ itab or offered by $\mathrm{A}$ rabic language course institutions.

If the students have completed some of these A rabic grammar branches, they will begin the actual religious lessons. The first and most important are usually figh, tawhid, and tafsir (interpretation) of The Qur'an. A fter completing the three main types of lessons, the students can take a side or additional lessons, such as tasawuf (Sufism), hadith, hisab (reckoning), or falak, which all depend on the expertise or attention of pesantren's kyai 
(Stenbrink, 1994: 171).

A part from being given individually, subjects are also given in groups, commonly in a circular seating to several students at once, which is called the halaqah system (classical) (Stenbrink, 1994: 171). In this system, a teacher reads the book line by line, translates, and if deemed necessary, the teacher will explain. In this way, a student can study a particular K itab broadly and deeply for several years. Such a teaching system is called a K itab subject teaching system, not a system of object studies, as found in conventional schools. A part from getting blessings from the mu'allif or the author of the book, a thorough study of the book, to the point of being able to finish it, supports the khatam culture, which is usually known as the end of as-sanah (year) (Stenbrink, 1994: 171).

The pesantren environment usually consists of a kyai's house, a place of worship (mosque or musalla), which al so functions as a place of education, one or more lodgings that the students make themselves, one or more rooms for cooking, and a pool or a room for bathing and ablution. In order to infuse the Islamic spirit into the heart of the students (santri), the pesantren's atmosphere is made in such a way that it is not only respected as a place for learning but is more emphasized as a place to live filled with religious values. There is no other place where obligatory prayers are established so strictly as in pesantren. A s an illustration, during the daylight, people in the pesantren's vicinity may hear the continuous recitation of The Q ur' an from the students (Stenbrink, 1994: 171).

For more in-depth religious study during the 19th Century, M ecca remained as the destination for studying. Thus, during this period, many pesantren kyai came from M ecca-style education (Stenbrink, 1994: 18). B efore then, it shifted to other Islamic countries, such as I raq, Y emen, and Egypt. The students never pay school fees and the like for their education because religious knowledge cannot be bought and sold for money (Stenbrink, 1994: 18). L ikewise, they do not pay the rent for the buildings available at the pesantren. On the other hand, the relationship between santri and kyai is generally a relationship of infinite obedience. Furthermore, the values of equality and brotherhood are the central values taught in pesantren-style education.

\section{Islamic Boarding School (Pesantren)}

In terms of terminology, it can be explained that the Islamic boarding 
school (pesantren) education, in terms of form and system, originated from India (W irjosoekarto, 1968: 40; A tjeh, 1957: 43; and Poerbakawatja, 1970: 1321). B efore the spreading of Islam in Indonesia, this system was generally used to teach Hinduism in J ava. A fter I slam entered and spread in Java, the system was then adopted by Islam through cultural acculturation or syncretism of cultural values. Like the term mengaji, the term pesantren does not come from an A rabic language term but rather from India. Likewise, the term pondok is not an A rabic term, but a term found in India (D hofier, 1982: 17).

$B$ esides the terminological reasons, the similarity in form betw een $\mathrm{H}$ indu education in India and pesantren in J ava, for example, can be considered as a guide to explain the origins of the pesantren education tradition. Soegarda Poerbakawatja (1970: 18-19), for example, mentions the similarity (Hindu education in India with Islamic boarding schools in Java) is in the model of the surrender of land by the state for religious purposes that are contained in the $\mathrm{H}$ indu tradition. Furthermore, the researcher looked at several elements found in the Hindu education system and the pesantren-style education system in Indonesia, which could not be found in M ecca's original Islamic education system. These elements include; the whole education system is religious, teachers do not get a salary, great respect for teachers, and students go "begging" outside the cottage environment (A tjeh, 1957: 43).

Some of the elements put forward by Soegarda, which stated that the pesantren education system originated entirely from Hinduism and not from Islam, is inaccurate because this system can be found in the Islamic world (Soebardi, 1972: 334). Likewise, the habit of the santri to travel frequently, which was found in pre-Islamic times in J ava, can al so be found in the Islamic tradition. In this context, M ahmud Y unus (1960: 31), for example, states that the origins of individual education used in Islamic boarding schools, as well as education that begins with A rabic lessons, can be found in Baghdad when it was the center and capital of the Islamic region.

Related to the tradition of surrendering land (perdikan) by the state for religious education, for example, can be found in the Islamic tradition in the waqf system. Furthermore, other elements can al so be found in Islamic culture. $M$ eanwhile, regarding the term used, it is not from the A rabic term, although the origin of the term pondok, perhaps comes from the A rabic word funduq, which means lodging or lodging for people who are traveling (Y unus, 1960: 31).

Regarding the tradition of handing over land, for example, in the 
historical context of the Indonesian Islamic education system, especially in Java, before the 19th Century, amid the significance of the role of Islamic boarding school ulama, its relationship with the rulers of the kingdom or palace at that time, was Sultan A gung. He offered the land to the santri community in pesantren to develop their educational institutions, including 300 pesantren (Stenbrink, 1984: 165-172). The perdikan land itself is a free piece of land with certain privileges, usual ly associated with a religious location where the ruler removes taxes and burdens from the state (palace). In the following period, the land of perdikan developed into a special village with certain religious functions, such as guarding holy places, maintaining Islamic boarding schools and mosques (Stenbrink, 1984: 165-172).

These pesantren are at least divided into large pesantren and "mother pesantren," namely the Takhassus pesantren with a specialization in Islamic knowledge and the Tarekat Pesantren (Darban, 1988: 32-38). Thanks to the dynamic process of Islamic education before the 19th Century, in Java in particular, along with the increasing number of pesantren, it might not be an exaggeration if M ahmud Y unus (1960: 226-227) consi dered learning activities during the M ataram period as the "golden age" of the Indonesian Islamic education system. From the Walisongo period in the 15th and 16th centuries to the Sultan A gung period in the 17th Century, there was no difference between the palace community and the pesantren community (Y unus, 1960: 226-227). A s a result of their harmonious relationship, in the 18th Century, several prolific writers worked for the sultan, who had a clear pesantren education in Java. Even though there was no better support from the Dutch colonials or the sultans to rectify the quality of traditional Islamic education in the 19th Century in J ava, there has been an embryonic growth (embryo) of Islamic educational institutions.

There are almost no sources of information regarding certain developments in pesantren, especially in the 19th Century. The pesantren showed a more vivid picture in the following period, with their success in responding to various internal and external challenges. It should be noted that pesantren functioned more as a cultural and educational institution, continuing the Walisongo tradition, rather than a political institution (D hofier, 1982: 100101). However, the relationship between the two elements, as happened before, is always inseparable. It should be remembered that the pesantren community's struggle in cooperating with pious sultans to fight against the 
D utch colonialism should be seen as a community inspired by their effective religious leaders than as an institution (D hofier, 1982: 100-101).

The pesantren in the 19th Century had a different panorama. The background of the establishment of Pesantren Tebuireng, J ombang, E ast J ava, as the oldest I slamic boarding school in J ava, in 1899, for example, reflects the symbolic relationship between ideological, cultural, and educational dimensions (Dhofier, 1982: 100-101). Nobody denies that Hasyim A sy' arie (1871-1947) aimed to establish the Pesantren Tebuireng was primarily to disseminate the knowledge he had acquired, both from J ava and A rabia ( $M$ ecca). M oreover, it could not be denied that his career and institutional development have a political dimension in narrow and broad meaning (D hofier, 1982: 100-101). It should be noted that there is a sugar factory there, namely the Cukir Sugar Factory, approximately 5 miles from the Tebuireng Islamic boarding school. The D utch founded the factory in 1853. A that time, sugar was a source of foreign exchange for the colonial government. This factory indeed became a symbol of modernization and industrialization for the colonial government. The establishment of the Pesantren Tebuireng vis-a-vis sugar factory owned by foreigners can be seen as an effort by the pesantren community to face Dutch hegemony. In reality, this master plan was followed by a series of non-cooperation, autonomy, and resistance to the colonialists (Dhofier, 1982: 100-101). During the same time, the pattern of conflict relations between pesantren-madrasah as a symbol of tradition, and the sugar factory (school) as a symbol of modernization occurs.

Pesantren Tebuireng is an example of the style of the emergence of the Islamic education system, which is not only for disseminating Islamic religious knowledge with traditional systems and methods but also for establishing an Islamic boarding school as an economic-political front to resist D utch colonialism. Thus, one cannot draw a linear straight line, regarding the cause of the establishment of other pesantren, to the estuary of perfom uniformity (M as' ud, 2006: 98). In other words, the establishment of an I slamic boarding school is not only for reasons of maintaining and disseminating Islamic-style education.

Researchers such as Soegarda (1970: 13-21) and A mir Hamzah (1968: 40), for example, hope that the pesantren tradition will remain sustainable, in addition to the education system (school) originating from the West. A part from the two, the closer relationship between Indonesian Islam and Islamic 
centers, especially M ecca, occurred since the steamship operation and the Suez Canal opening. All of this evidence proves that the practice of Islamic education in the 19th Century was, in general, an attempt to adapt to the I slamic education given in M ecca. A s M ecca is the city where all the thick and thin books come from, all the pesantren's leading guru in I ndonesia gets their education (Stenbrink, 1994: 18).

\section{Shifting THE TRADition OF THE CONVENTIONAL SCHOOL AND MADRASAH EDUCATION}

\section{Individuals}

The 1906 report provided a detailed and interesting picture of a madrasah in Surakarta; " "T he Islamic high schools (madrasah) established by Susuhunan Pakubuwono, which are combined with the mosque, have 14 teachers and 325 students. Religious lessons consist of reading and memorizing The Qur' an, Safinah $\mathrm{K}$ itab, and U mm al-B arahain. Furthermore, lessons are given in A rabic, with several additional lessons being taught: astronomy, knowledge of the sun's circulation, calculations of solar eclipses, algebra, and logic. At that time, this school could be considered a pioneer in reforming Islamic education in Indonesia, including incorporating several Western education elements into the curriculum of Islamic education in Indonesia (Stenbrink, 1994: 18).

In 1907, A bdullah A hmad² established a school in Padang Panjang, M inangkabau, West Sumatra. In contrast to education in Surau, in the A dabiyah school, the classical system was applied and implemented consequently (Stenbrink, 1994: 37). A part from religious lessons, lessons on reading and writing $L$ atin letters and arithmetic in this school are also provided. A bdullah A hmad included four D utch teachers and two I ndonesians, who also had certificates to teach at the HIS level. In 1916, the A dabiyah

${ }^{1} \mathrm{~A}$ Igemeen Verslag van bet Onderwijs, is a general report on education during the $\mathrm{Dutch}$ East Indies period. The report is not very interesting because the information about Islamic education is provided in general nature and often far from complete.

${ }^{2}$ Is a figure of Islamic reform in M inangkabau. In 1895, at the age of 17 , hewent to M ecca to perform the pilgrimage and to study religion. When he returned to West Sumatra in 1899, he went straight to Padang Panjang to help his father teach in Surau. L ong story short, under the influence of the educational idea of Thahir J alal uddin, a friend from his area, who had studied at al-A zhar, Cairo, founded the A dabiyah school in Padang Panjang. 
school was recognized by the government as the first HIS founded by a Muslim. The following year, the school received full subsidies from the governorate. The difference between the A dabiyah school and HIS is the provision of 2 hours of religious instruction per week, provided by A bdullah A hmad himself. HIS schools are generally only open to children of employees and certain families, while A dabiyah schools are open to those who can pay tuition fees (Stenbrink, 1994: 37).

In 1916, Zainuddin Labai ${ }^{3}$ founded M adrasah Diniyah, an afternoon madrasah for religious education organized based on a classical system and did not follow the traditional individual recitation system (Y unus, 1960: 59). L ikewise, the lesson structure is different from the others, namely starting with basic A rabic knowledge before starting to read The Q ur' an. A part from religious education, general education was also given, especially history and geography. The Egyptian method is used in the implementation of education (Yunus, 1960: 59).

\section{Islamic Organizations}

In 1919, Zainuddin L abai took the initiative to establish the A ssociation of Islamic Religious Teachers (PGA I) ${ }^{4}$ in $\mathrm{M}$ inangkabau and became the first head of this organization. Unlike Sumatra Thawalib, PGAI is more involved in religious matters, especially in modern religious school education. $A$ few months after reformist teachers in M inangkabau founded PGAI, more traditional teachers founded the Sumatran Ulama A ssociation (Y unus, 1960: 82).

Nine (9) years later, on M ay 5, 1928, to be precise, the Sumatran Ulama A ssociation merged with the establishment of the Islamic Tarbiyah A ssociation (PERTI), at the house of Sulaiman ar-R asuli, a Tariqah $\mathrm{N}$ aqsyabandiyyah murshid. At the meeting, the association also decided to take some classical education elements to improve their education. The person who strongly defended this change was Shaykh A bbas, where he was the only

${ }^{3}$ The reform of I slamic education, which has drawn reactions from outsiders, does not start from big cities, but from small cities. The most important motivation comes from a strange character, but has a strong personal ity, one of which is Zainuddin L abai (1890-1924). In 1906, while still a student and helping to teach Hamka, he founded M adrasah Diniyah

${ }^{4} \mathrm{PGA}$ I is an association of religious teachers formed by the young people. Several months later, a group of religious teachers from the el derly founded the Sumatran U lamaA ssociation. 
old cleric who had used the classical system, by establishing the A rabiyah School in 1918, and in 1924 establishing a second school in Bukit Tinggi with the name Sekolah Islam/I slam School (Yunus, 1960: 82).

On N ovember 18, 1912, A hmad D ahlan founded the M uhammadiyyah organization (Hamzah, 1968: 87). In addition to establishing schools that followed the governorship model, M uhammadiyah, in a short time, also established schools that were more religious in nature (Hamzah, 1968: 87). The schools like madrasah diniyah in M inangkabau are intended to replace and improve the traditional Qur' an recitation method. For the recitation of religious books (K itab), M uhammadiyah is also looking for a replacement in accordance with the demands of modern times; this effort can be seen as a realization of the Sarekat Islam plan, which since 1912 has been trying to establish a religious education school, which can compete with the colonial governor's teacher education school.

In 1901, the A rab community in J akarta established schools and madrasah, intending to provide better general and religious education. This first attempt failed. How ever, in 1905 the al-Jami'ah al-K hairiyyah organization succeeded in establishing the first school for the A rab community in J akarta. In Indonesia, al-J ami' ah al-K hai riyyah was the first organization founded by non-D utch people, whose overall activities were carried out based on the Western system (A tjeh, 1957: 321). That way, the organization meets the requirements for official recognition from the government. The curricula of these first madrasahs consisted of general subjects (English) and religion (A rabic).

In 1913, a group labeled as reformists or modernists from the al-Jami'ah al-K hairiyyah organization, because they did not respect the title of sayyid, founded the organization J ami' ah al-Islam wa al-Irsyad al-'A rabiya, which is generally referred to as al-Irsyad, led by A hmad Surkati (N oer, 1963: 96-100). B ecause this organization's school equipment comes from the M iddle East, the education system is al so applied according to the M iddle Eastern model, especially in Egypt and Tunisia. The schools managed by the two organizations (al-Jami'ah al-K hairiyyah and al-lrysad) are no different from the governorship's education system, al though both provide more religious education opportunities. In this way, A rab community groups also contributed to accepting the Islamic education system's reform, according to the Western system (Stenbrink, 1994: 62). 
In 1916, A bdul Wahab Hasbullah, after returning from M ecca, founded the J ami' ah Nahdah al-Watan, with Haji M as M ansoor, who had just returned from studying in Egypt. Egypt at that time could be considered a more modern center of teaching than M ecca. This Jami' ah aims to improve religious education through a well-structured system, including the classical system (Stenbrink, 1994: 65). In 1922, M as M ansur entered the M uhammadiyyah organization, so he left his education duties, and he also left J ami'ah Nahdah al-Watan.

M eanwhile, Wahab Hasbullah, related to the issue of the abolishment of the Turkish caliphate at that time, and to defend the independence of the Syafi'i school of thought in the city of M ecca, which was then controlled by Wahhabis, ${ }^{5}$ formed its committee called the " Committee for Deliberating Hijaz" (Stenbrink, 1994: 68). Starting from this committee, on J anuary 31, 1926, the Nahdah al-'Ulama'(NU) was founded. NU did emerge as a protest against the reformist movement and the need to have an organization that defended the Syafi' i school and rivaled the M uhammadiyyah and al-I rsyad organizations (A tjeh, 1957: 471-472).

The initiative to reform the education system in Islamic boarding schools' style did not come from NU's el ders, but rather from the oldest student of $\mathrm{H}$ asyim A sy' arie's himself named M ohammad Ilyas, nephew of Hasyim, and A bdul Wahid Hasyim, his own son (A tjeh, 1957: 83-99). In 1925, M ohammad Ilyas completed his HIS education and later settled in Tebuireng to study religion. A fter staying for some time, he was assigned as the general supervisor of some part of the boarding school and became the Salafiah Islamic Boarding School leader in 1929 at the age of 18. M adrasah Salafiyah is a madrasah with a classical system, founded in Tebuireng in 1916, for the recitation of The Qur'an. With the approval from K.H. Hasyim, M ohammad Ilyas includes general subjects such as reading and writing Latin characters, geography, history, and $M$ alay.

${ }^{5} \mathrm{~A}$ t that time, the title Wahabi was given to all modernists, who no longer wanted to pledge to a particular school of thought. Therefore the followers of the Syafi' $i$ mazhab are afraid that the station of I mam Syafi' $i$ will be dismantled, and that his teachings should no longer betaught in M ecca. Even though M ecca, for traditional groups at that time, was still the most preferred college.

${ }^{6}$ D ue to Rabindranath Tagore's influence with his "Shantiniketan", A bdul Halim chose the countryside as the ideal environment for his school. A s a memory for Tagore, the name of the school was given a name similar to "Shantiniketan", namely Santi A srama. 
A though $\mathrm{K} . \mathrm{H}$. Hashim A sy' arie is quite conservative, reforms at the pesantren have caused quite strong reactions (Stenbrink, 1994: 71).

In 1932, A bdul Halim succeeded in establishing "Santi Dormitory," 6 namely a boarding school (Stenbrink, 1994: 75). Besides being given religious and general lessons in these schools, students are also given education in skills, such as agriculture, carpentry, and wood carving. The motive for establishing a school with such a distinctive curriculum is that the governor's school only prepares students for office work. M ost of the graduates of this school in the 1930s did not find jobs in public and private offices. By equipping students with special skills, it was hoped that they could live independently (Stenbrink, 1994: 75).

On N ovember 30, 1930, in M edan, Jami'ah al-Wasliyyah was founded, aiming to develop religion in a rather broad sense (AIfian, 1969: 358-382). Jami' ah al-Wasliyyah is a conservative group of the M uhammadiyyah organization, which is considered modernist. Jami' ah al-Wasliyyah adheres to the Syafi' i school. What is different from M uhammadiyyah was Jami'ah alWasliyyah places much emphasis on madrasah, namely schools that prioritize religion (Alfian, 1969: 358-382).

\section{The Government}

A the beginning of the 20th Century, there were several changes and reforms in Islam in Indonesia, ${ }^{7}$ which in outline can be described as enlightenment (Stoddard, 1966: 295-323). One of the most important driving factors for Islamic change in Indonesia at the beginning of this Century is Islamic education renewal (Stenbrink, 1994: 26). Because many M uslims and Islamic organizations were dissatisfied with traditional methods (pesantren) in studying The Qur' an and religious studies, individuals, organizations, and

${ }^{7}$ A ccording to A boebakar A ceh, for example, the patterns of reform that occurred in Indonesia during the 20th century were divided into three (3) groups: First, the salaf movement (the movement of previous people who wanted to return to the tracks of the sal af ulama which was also chosen by J amaluddin al-A fgani to name his movement as the salafiah movement. In discussing the salaf movement in Indonesia, special attention is paid to A bdullah A hmad and hisA dabiyah school, the A rab M usl im organization (J ami' ah K hairiyah and al-Irsyad). Second, the modernist movement which is political in nature. Third, modern movements that do not agree with critical views of Islamic history, and do not need to return to the true teachings of Islam. This movement simply wants to expect outside change, not the soul of its teachings. The modern movement being discussed is the Islamic U mmah M ajalengka Union, J ami ' ah al-Wasliyah, Perti, and Nahdah al-Ulama'. 
state institutions (M inistry of Religious A ffairs) tried to improve the Islamic education system both in terms of method and content at the beginning of the 20th Century. They also worked out the possibility of providing general education for M uslims (Stenbrink, 1994: 26).

In this section, related to the efforts to reform the Islamic education system in the 20th Century, theauthor only explores the role of the Republic of Indonesia's government since 1945, and in this case, especially the M inistry of Religious A ffairs (during the N ew Order Government it was called Departmen A gama or Department of ReligiousA ffairs) which was established on J anuary 3, 1946. This $M$ inistry's formation is a policy that has been planned for a long time and is not a 100 percent new M inistry (Boland, 1971: 37). Several government activities related to religion, which had existed since the colonial era and the J apanese occupation, were continued by establishing a religious $M$ inistry.

During the Dutch colonial era, a religious office was established, with the official name "K antoor voor Inlandsche Zaken." M eanwhile, during the J apanese colonial period, it was named "Shumuka," which served as a general advisor in religious matters. In its later development, the M inistry of Religious A ffairs, apart from being tasked with appointing the penghulu, also developed new activities, which were different from those carried out before. In a short period, this new task became the government's coretask (A tjeh, 1957: 598). The government's participation in religious matters, which at first was only in administrative matters and security supervision, was then developed with several activities aimed at providing a positive impetus for the appreciation of religion, especially in the field of education (A tjeh, 1957: 598).

In the field of religious education, in mid-1944, for example, K.H. A bu $D$ ardiri had suggested that religious instruction be given in all village schools in his regency ( $K$ aresidenan $B$ anyumas) so that students would become good people in the future (A tjeh, 1957: 598). The central religious office in J akarta later approved this proposal. The same approval was given to other regencies, such as Kediri and Pekalongan.

From the data that has been presented, it appears that a positive line of religious education policy began with the religious office in the Japanese era. The M inistry of R eligious A ffairs vigorously continued this policy after 1944. In one of the notes on Islamic Education in Indonesia, compiled by the M inistry of Religious A ffairs education department on September 1, 1956, it is described as follows: First, giving religious lessons in public schools and 
particulars. Second, provide general knowledge in madrasah. Third, holding Religious Teacher Education (PGA) and State Islamic Judge Education (PHIN) (A tjeh, 1957: 632-633).

The first and second types above are linked to the dualistic education that emerged in Indonesia, since the end of the 19th Century, due to the D utch government not paying attention to existing Islamic educational institutions, which leads to the independent establishment of the local I slamic education system. This education system is then called the school system, separated from the education system that specifically pays attention to religious education. In the Indonesian government, this school system was then included in the $M$ inistry of Education and Culture (A tjeh, 1957: 632-633).

We have seen several I slamic education initiatives to conform to general education, using policies and legislation and subsi dies from the $D$ utch colonial government. However, most I slamic educational institutions choose another path, for example, where a number of simple Qur' anic recitation institutions and Islamic boarding schools did not make changes before 1945. However, many others are increasingly developing by changing methods, incorporating the classical system, regular school years, changing the content of education, providing general education, and religion, which is the most important part of the curriculum (Stenbrink, 1994: 88).

This religious institution did devel op in a direction similar to the school system. How ever, it is different because it emphasizes religious teaching. This kind of education system is what we later call the madrasah system; both have added general lessons or still maintain 100\% religious lessons (Stenbrink, 1994: 88).

The madrasah system and religious teaching provided with the school system fall under the M inistry of ReligiousA ffairs' authority. This M inistry's policy objective is mainly to eliminate the dualistic differences between the general school system and the madrasah system. On the other hand, the $M$ inistry does not really interfere with the pesantren education system. It only advocated modernizing and taking over the madrasah system. Consequently, on the one hand, providing wisdom to include as much religious teaching as possible in the school system while also paying attention to general sciences in the madrasah system (Stenbrink, 1994: 88). Through the slowly expected convergence, the two separate or dualistic educational systems, since the beginning of the twentieth Century can be united or integrated again. 
Saefudin: The Shift in The Tradition of Islamic Education... (page 1-23)

\section{a. Religious Education in Schools}

The M inistry of Religious Affairs' policies consistent with the school system, which are regulated under the $M$ inistry of Education and Culture, are intended so that existing religious education is expanded and developed. In colonial times there were laws that allowed religious education in public schools. Several schools that use theWestern education system are given very little religious lesson. Only a small proportion of the Gubernemen-paid schools provide Islamic religion lessons- moreover, the M inistry of Religious A ffairs' desires to improve this situation.

On the other hand, the M inistry of Education and Culture does not like to increase religious education because there are quite a number of people who are only willing to provide limited opportunities for religious education in this $M$ inistry. Until a prominent figure whose thoughts underlies the M inistry of Education and Culture's attitude in the future, namely K i Hajar D ewantara, leader of Taman Siswa and the first M inister of Education and Culture (13 A ugust-27 N ovember 1945), conveyed his thoughts (Stenbrink, 1994: 90). He views religious education, especially as merely moral education (akhlaq), and disagrees with religious education (formally) as an introduction to figh in general in Islam (Poerbakawatja, 1970: 55).

On December 27, 1945, the Central National Committee Worker B ody (BPKNP) held a discussion on the national education outline. The results of these discussions formed a special commission to formulate the outline of education in Indonesia in more detail. In the report compiled by the committee, it is proposed about religious education, four of which are related to religious teaching. First, religious teachers are also required to be proficient in general education. Second, there are exercises for religious teachers. Third, the quality of pesantren and madrasah must be improved. Fourth, teaching A rabic is not needed (Poerbakawatja, 1970: 37-45).

The first official regulations regarding education can be found in the Education Law of 1950, number 4, and the Education Law of 1954 No. 20. The M inistry of Education and Culture's joint regulation and the M inistry of Religious A ffairs' issued on J anuary 20,1951, also stipulated that religious education should be given from grade IV of the People's School (SR) for 2 hours per week. M eanwhile, the curricul um and religious learning materials are stipulated by the M inister of Religious A ffairs and the M inister of Education's approval. 
In the 1960 M PRS session, it was also stipulated that religious education should al so be included in public universities by giving students the freedom to follow or not participate in this religious teaching (Said, t.t .: 530). Until 1967, the M PR S changed the 1960 decree by requiring students to attend religious teaching or lectures and not allowing them not to attend them. Since then, religious teaching has also played an essential role in the assessment of pupils and students. This education's implementation began to be required from grade 1 elementary school (Ekowardono, 1970: 276). The MPRS decision was then followed by a joint regulation by the $M$ inister of Religious A ffairs and the M inister of Education and Culture on October 23, 1967.

In the late 1970s, the M inister of Religious A ffairs attempted to change the religious teaching curriculum. All the highest SD and SM P grades had 6 hours of religious instruction per week. However, this effort was not successful because the M inistry of Education disapproved of it (Stenbrink, 1994: 94). However, this latest effort proves that the M inistry of ReligiousA ffairs' policy regarding schools is relatively consistent and continues to real ize that the first part of the convergence to expand religious education in schools.

A s reflected in the M inistry of R eligious A ffairs and the M inistry of Education and Culture, the dualistic education system has originated from the colonial era as an anti-Islamic effort by the Dutch (Stenbrink, 1994: 94). Therefore, from within the M uslim community, there was an attempt to negate this colonial heritage by bringing the entire education system under the supervision of the M inistry of Education and Culture (Stenbrink, 1994: 94).

A part from the above views, other assumptions state that this different type of education system's emergence is a sign of decline for I slam itself. This assumption gives a deep impression that Indonesian society has not accepted Islam completely and fundamentally from the start. Thus, there are often conflicts between groups who strictly and purely carry out Islamic religious orders fully (kaffah) and groups that only implement Islam in bits and pieces (Stoddard, 1966: 368). A part from that, it cannot be denied that the reform of the Islamic education system in Indonesia, with its various variants, has hel ped accelerate Islamization in Indonesia.

\section{b. General Education in M adrasah}

The committee that formulated the educational policy, formed at the end of 1945, in its report on the old and new forms of I slamic education stated that: 
M adrasah and pesantren, which are essentially a means and source of education and intelligence for the common people, which are deeply rooted in Indonesian society in general, should also get real attention and assistance with guidance and material assistance from the government (Poerbakawatja, 1970: 38).

In the context of convergence, the M inistry of Religious A ffairs recommends that traditional pesantren be developed into a madrasah, arranged classically, using a fixed curriculum and incorporating general lessons in addition to religious lessons. In this context, the M inistry of Religious A ffairs only assists madrasas that also pay attention to general education. On the other hand, formally, the M inistry of R eligious A ffairs has benefited from L aw 1950 article 10, which states that studying at a religious school that has been recognized by the M inistry of Religious A ffairs is considered fulfilling the obligation to study (Poerbakawatja, 1970: 348).

In the 8 Y ear Development Plan (1961-1969), which was passed by the government to the MPRS, it was stated that madrasah (which also teach general subjects) would devel op to follow the type of public schools and would eventually come under the authority of the M inistry of Education and Culture. A ccording to this concept, the M inistry of Religious A ffairs' task was ultimately limited to education to meet the M inistry of Religious A ffairs staff's needs. For this transitional period, madrasah must be guided more intensively by the M inistry of Education and Culture to achieve the goal of integration in schools (Poerbakawatja, 1970: 348). N evertheless, the M PRS itself, in 1960 and then 1963, stipulated that madrasah would remain under the $\mathrm{M}$ inistry of Religious A ffairs.

The policy of convergence or synthesis that has been carried out by the M inistry of R eligious A ffairs has not yet reached its target (Stenbrink, 1994: 102). B ecause on the one hand, it is an open secret that in the field of general subjects, the madrasah system cannot compete with the general school system. On the other hand, the M inistry of R eligious A ffairs has al so failed to devel op religious subjects that are given in public schools, nor can it compete with those given in madrasahs. In addition, A rabic is not a compulsory subject in public high school, in contrast to English, which is the first foreign language at the school. In public high school, A rabic is only an optional subject that is often not taught and is not an option in high school (Stenbrink, 1994: 102).

Recent developments show, especially in the early 21st Century, that the 
M inistry of Religious Affairs has carried out several policies related to integrating the Islamic education system with the public school education system. Three of them are as follows; First, there is an equality test for madrasah alumni (Package $C$ exam) to get an equality diploma and continue their studies to college, to both Islamic universities and public universities. Second, collaborating with the M inistry of Education and Culture, in the form of sending madrasah alumni in Islamic boarding schools, to get scholarships to study at favorite public universities, such as UGM , ITB, and IPB. Third, changing the Islamic Higher Education (Madrasah) (IAIN) system to an integrated school system (UIN). Thus, UIN is a kind of prototype, at least for now, as the ideal form of an integrated Islamic education system. At which the intermediate level, UIN is a combination of the education system in M adrasah and Sekolah.

B ased on the description above, there is an attempt to change education in Indonesia, as seen by the new devel opments and changes from the pesantren system to the madrasah system, the development from traditional methods to classical education. However, it is often said that this effort is a manifestation of the convergence and synthesis effort in the field of education, where madrasahs are given the position as an educational institution, which fulfills the balance between Eastern and Western education, pesantren (madrasah) and schools, religious and secular (general ). However, so far, the impression that has emerged is that this balance is increasingly heavy towards the public school model, as a general education model that will be implemented throughout Indonesia, which will result in the Islamic education tradition that will begin to disappear.

\section{INTEGRATION OF EDUCATION SYSTEMS THAT BECOME A TRADI- TION AND ALTERNATIVE}

Higher education (schools) and pesantren (madrasah) are two educational system traditions that have many differences. Higher education (school) is a symptom of a city; a pesantren (madrasah) is a symptom of a village. Higher education is synonymous with modernity; pesantren is synonymous with traditionality. Higher education places more emphasis on a liberal approach; pesantren emphasizes its conservative attitude. This kind of dualismdichotomic perception may not be very precise because, in reality, many Islamic boarding schools have also made changes, both culturally and 
structurally (Fadjar, 2006: xxi-xxvii).

If recently we have witnessed a convergence or synthesis between pesantren and higher education institutions, then this can be seen as a constructive development. As we know, recently, many Islamic boarding schools have established universities, and vice versa, universities have established I slamic boarding schools. A Iternatively, in some cities, I slamic boarding schools with a sense of higher education have started to be established. However, in them, no form of education is formally called higher education. O ne example is the N urul J adid Paiton Probolinggo I slamic B oarding School, which has established an institute of higher learning. In M alang, for example, there is Pondok Pesantren al-Hikam, whose attendees are university students (Fadjar, 2006: xxi-xxvii).

The above phenomenon, where the two educational systems, which reflect differences in institutional terms and philosophically and culturally, suddenly approach each other, thus leading to convergence. Perhaps this is what is called the post-modern era in the 21st Century. In this era, we witness a form of world reality that begins to show unity, but at the same time plurality. The most common example is the great tendency of globalization to make the other w orld transparent. N evertheless, in this gl obalization, we face plural ity matters, where the world is no longer divided in a dualism-dichotomic way (F adjar, 2006: xxi-xxvii). In cultural life, we witness the close each other between traditional discourse (pesantren and madrasah) and modern discourse (school). The world of education seems unable to get away from this big current. So the old pattern of education, namely traditional education (pesantren) on the one hand, and modern education (school) on the other are now starting to be criticized by many people because it only presents a lame personality or even split personality.

\section{E. Conclusion}

B ased on the explanation above, the authors conclude that the relationship pattern between Islamic (pesantren-madrasah) and the regular education system is associated with Indonesia's I slamic education system development. This pattern occurred in the 19th to the beginning of the 21st Century and is divided into two episodes. During the first two centuries, namely the 19th and 20th centuries, the Islamic education system (religious sciences) - whether organized by individuals, organizations, or government 
institutions - was still differentiated (convergence or synthesis) from the school education system (general sciences). At the beginning of the 21st Century, the relationship between the two education systems has indicated the integration of knowledge, although it is still constrained. So far, it has been rigidly divided between "religious sciences" on the one hand and "general sciences" on the other, leading to an integrated knowledge discourse. If this pattern is desired, an Islamic boarding school for higher education will be created. In which "general knowledge" is given during the day, and "religious knowledge" of religious (yellow) K itab is taught in the evening. This tradition has become a model for curriculum synthesis between the religious sciences and the general sciences to form the Islamic higher education institution.

\section{REFERENCES}

Ali, Mukti. 1970. Pelbagai Persoalan Islam di Indonesia Dewasa Ini, Jogjakarta: tnp.

A rif, M ahmud. 2006. "Tradisi Bayani dalam Pendidikan Islam: Kajian Historis-Filosofis A tas E pistemologi Pendidikan Islam M asa K eemasan dan Implikasinya Terhadap Pendidikan Islam di Indonesia", dalam Rachman A ssegaf (ed.), Pendidikan Islam: Dalam Konsepsi dan Realitas, Cet. I, Jogjakarta: Lembaga Penelitian UIN Sunan Kalijaga. A tjeh, A boebakar. 1957. Sejarah Hidup K.H. Wahid Hasjim dan Karangan Tersiar, J akarta: tnp.

A Ifian. 1969. Islamic M odernism in Indonesian Politics: The M uhammadiyah M ovement During the Dutch Colonial Period 1912-1942, ttp. : tnp.

A I-A sfahani, ar-Ragib. T.t. M u'jam M ufradat li Alfaz The Qur'an, B eirut: Dar al-Fikr.

Boland, B.J. 1971. The Struggle of Islam in Modern Indonesia, ttp. : The Hague.

Berg, Van der, L.W.C. 1886. "Het M ohammedaansche Godsdtientonderwijs op J ava en M adoera en de Daarbij G ebruikteA rabische B oeken", dalam Tijdschrift voor Indische Taal, ttp. : tnp.

Brugmans. 1938. Geschiedenis van het Onderwijs in Nedherlandsch-Indie, ttp. : tnp., 1938.

Chijs, Van der. 1864. Bijdragen tot de geschiedenis van het Inlandsch Onderwijs in Nederlandsch-Indie, ttp. : tnp.

- - - . 1865. Verslag van het Inlandsch Onderwijs O ver, ttp. : tnp.. 
Dhofier, Zamakhsyari. 1982. Tradisi Pesantren, Jakarta: LP3ES.

Darban, A . A daby. 1988. "K iai dan Politik pada Zaman K erajan I slam J awa", dalam Pesantren, 5, No. 2, 1988.

Fadjar, M alik. 2006. "Sintesa antara Perguruan Tinggi dan Pesantren: U paya M enghadirkan Wacana Pendidikan A Iternatif", dal am M udjia R ahardjo (ed.), Quo Vadis Pendidikan Islam: Pembacaan Realitas Pendidikan Islam, Sosial, dan K eagamaan, M alang: UIN M alang Press.

Hurgronje, C. Snouck. T.t. Verspreide Geschriften, ttp. : tnp.

Hasjmy, A . t.t. "K onsep Ideal Darussalam", dalam 10 Tahun Darussalam, ttp. : tnp.

Hamka. 1949. "Faham Soekarno", dalam M uchlis (ed.), Tinjauan Islam Ir. Soekarno, Tebing Tinggi: tnp.

M as' ud, A bdurrahman. 2006. Dari Haramain ke Nusantara: J ejak Intelektual A rsitek Pesantren, Cet. I, Jakarta: K encana.

Noer, Deliar. 1963. The Rise and Development of the Modernist Muslim M ovement in Indonesia During the Dutch Colonial Period 1900-1942, A merika: Cornell University Press.

Natsir, M ohammad. 1969. Kubu Pertahanan M ental dari A bad ke A bad, Surabaya: tnp.

- - - . 1961. Capita Selecta II, Jakarta: tnp.

Poerbakawatja, Soegarda. 1970. Pendidikan dalam A lam Indonesia M erdeka, Jakarta: tnp..

Rahman, Fazlur. 1984. Islam, terj. A hsin Muhammad, Cet. I, Bandung: Pustaka.

Soebardi. 1927. Santri-Religious Elements as Reflected in the Book of Thentini, ttp. : tnp.

Steenbrink, K arel A. 1994. Pesantren, Madrasah, dan Sekolah: Pendidikan Islam dalam K urun M odern, Cet. II, Jakarta: LP3ES.

- - - - . 1984. Beberapa A spek tentang Islam di Indonesia A bad ke-19, Jakarta: Bulan Bintang.

Stoddard, L othrop. 1966. D unia B aru Islam, terj. A boebakar, Jakarta: tnp.

Soekarno. 1963. Di Bawah Bendera Revolusi, Jakarta: tnp.

Wall, Van der. 1963. Het Onderwijsbeleid in Nederlandsch-Indie, ttp. : tnp. Wirjosoekarto, A mir Hamzah. 1968. Pembaruan Pendidikan dan Pengajaran Islam, M alang: tnp.

Yunus, M ahmud. 1960. Sejarah Pendidikan Islam di Indonesia, Jakarta: tnp. 